\title{
Art as an instrument to develop communicational skills
}

In this comment we continue with the series entitled "Art as an educational tool in medicine". This time, we would like to stress the need to convey the main characteristics of a good communicator to medicine students, physicians and health care providers. ${ }^{1}$

Such educational goal should be considered as a priority because learning and practicing these communicational skills is what allows medical (scientific and technical) knowledge to effectively benefit patients by inspiring in them the trust and hopes necessary to forge an adequate treatment environment. In addition, effective communication allows patients to clearly understand what their disease is and the proposed therapeutic strategy, thus encouraging compliance (adherence); this way, patients may also turn into a treatment ally (empowerment). ${ }^{2-6}$

Below we will briefly describe the inherent characteristics of a good communicator.

During an act of communication, a good practice is to refrain from giving an opinion before having evaluated the interlocutor's characteristics, i.e.: having understood what they want (or do not want) to know about their disease and how much they already know, in addition to testing the type of language (code) that should be used and their present emotional status. This is because for communication to be effective, it should be based on honest listening, which means being empathetic to our interlocutor (transient dissolution of the ego), paying attention not only to words (linguistic channel), but also to their intonation (paralinguistic channel) and to body language (gestural channel). ${ }^{2,7}$ Therefore, only after knowing the interlocutor, it may be possible to come up with a discourse plan based on our assessment, and such discourse should be clearly expressed, avoiding the use of ambiguous terms (polysemy), weighing up the emotional burden of our words (connotation) in advance, being careful about how and where they are expressed (paralanguage and non-verbal language), and making a case for everything we say (persuasion). ${ }^{2,8}$ Such attributes may be acquired by combining different educational strategies, for example, theoretical information on communicational principles and public speaking (courses), analysis of works of art (literature and movies) dealing with this subject, and interactive workshops that allow to reenact daily medical practice situations that require to be solved through adequate communicational skills (communication of bad news, etc.). ${ }^{9-11}$

Below are some examples of communicational events presented in important works of universal literature which are very helpful due to their clarity:

- In The Death of Ivan Ilyich by Leo Tolstoy, the author describes the inability of medicine to provide emotional comfort to a sick person. For example: Ivan Ilyich gets involved in a poor doctor-patient communication that leads him to develop feelings of confusion and grief. The doctor's bad attitude towards Ivan, his pride, secrecy, systematic underestimation of Ivan's questions and the use of highly technical language to explain things lead Ivan to multiple consultations, misinformation and doubt: ${ }^{9}$

"To Ivan Ilyich only one question was important: was his case serious or not? But the doctor ignored that inappropriate question."

- In The Misunderstanding by Albert Camus, the author describes how dysfunctional communication may lead to disaster. In the play, a woman (Martha) and her mother run a guest-house in which they murder solitary male travelers to steal their money. One day, her brother, who they have not seen for several years, books at the guest-house but conceals his identity for the purpose of surprising them. Days go by and he does not know how to tell them, until they kill him in complete ignorance of the situation. ${ }^{10}$

"...one word would have been enough... but he couldn't find the right one and while looking for words, they killed him..."

To sum up, acquiring communicational skills is essential for the comprehensive education of health care professionals, and art may become a greatly useful resource in this regard.

Carlos G. Musso, M.D., and Paula A. Enz, M.D. School of Medicine, Instituto Universitario del Hospital Italiano de Buenos Aires, Argentina

http:/ /dx.doi.org/10.5546/aap.2016.eng.4 


\section{REFERENCES}

1. Musso CG, Enz PA. El arte como instrumento educativo en medicina. Arch Argent Pediatr 2014;112(6):494-5.

2. Musso C, Enz P. Comunicación médico-paciente: la matriz del acto médico. Rev HospItal B. Aires 2006;26(2):77-8.

3. Musso CG. Obras maestras del arte universal y la medicina: Esta noche se improvisa por Luigi Pirandello (1867-1936). Evid Actual Práct Ambul 2008;11(5):145.

4. Musso CG. El médico asistencial piensa como científico y actúa como artista. Evid Actual Práctambul 2006;9(6):175.

5. Musso CG. El arquetipo asclepiano: su luz y su sombra. Evid Actual Práct Ambul 2005;8(2):60.

6. Musso CG. Obras maestras del arte universal y la medicina: Pigmalión de George Bernard Shaw (1856-1950). Evid Actual Aráct Ambul 2008;11(4):114.
7. Musso CG. La casa de Bernarda Alba de Federico García Lorca (1898-1936). Evid Actual Práct Ambul 2013;16(1):17.

8. Musso CG. El órgano-lenguaje. Evid Actual Práct Ambul 2005;8(4):124.

9. Musso CG. Obras maestras del arte universal y la medicina: La muerte de Ivan Ilich (León Tolstoi 1828-1910). Evid Actual Práct Ambul 2007;10(3):80.

10. Musso CG. Obras maestras del arte universal y la medicina: Elmalentendido: de AlbertCamus (1913-1960). Evid Actual Práct Ambul 2008;11(2):48.

11. Cacchiarelli San Román N, Musso CG. Enseñando a comunicar malas noticias en medicina. Una experiencia en el Hospital Italiano. Rev Hosp Ital B. Aires 2004;32(4):178-81. 